\title{
Kun aatteet haastoivat tradition: tutkimus 1960- JA 70- luvun poetiikasta ja runouskäsityksistä
}

\author{
Anna Möller-Sibelius 20 I8: Dikt och ideologi. Gösta Ågrens, Lars Huldéns och Claes \\ Anderssons 1960-1970-talspoesi. Helsingfors: Svenska Litteratursällskapet i Finland \& \\ Stockholm: Appel förlag. $391 \mathrm{~s}$.
}

Aatteet ja runous kytkeytyvät kirjallisuushistoriassa toisiinsa monin eri tavoin. Anna Möller-Sibeliuksen teos Dikt och ideologi lähestyy ideologioiden ja lyriikan vuorovaikutusta fokusoimalla kolmen suomenruotsalaisen runoilijan tuotantoon politisoituneen ja yhteiskunnallisen taiteen valtakaudella, 1960- ja 70-luvulla. Tutkimuskohteena olevat runoilijat Gösta Ågren (s. 1936), Lars Huldén (1926-2016) ja Claes Andersson (1937-2019) ovat pitkän uran tehneitä ja tuotteliaita kirjailijoita. Tutkimus keskittyy heidän varhaistuotantoonsa, jota yhdistää modernismin perinteen uudelleenarviointi ja uudenlaisen runollisen ilmaisun pariin hakeutuminen, yhteiskunnallis-sosiaalinen kantaaottavuus sekä demokraattinen runouskäsitys. Dikt och ideologi on julkaistu myös open access -julkaisuna, joten se luettavissa ja ladattavissa ilmaiseksi kustantajan sivuilla.

Teoksen tarkoitus on luoda katsaus 60- ja 70-luvun suomenruotsalaiseen lyriikkaan tarkastelemalla ideologian ja runouden kohtaamista kolmen runoilijan tuotannossa. Kirjallisuushistoriallisen tiedon tuottamisen yhdeksi motiiviksi mainitaan ideologian ilmiöiden parempi ymmärtäminen aikana, jolloin poliittiselle, yhteiskunnallisella ja kantaaottavalle runolle on selvästi kysyntää. Samalla tekijä muistuttaa, että runot ovat myös itsessään lukemisen arvoisia. Möller-Sibelius poimii aineistostaan lukuisia kiehtovia esimerkkejä, jotka yllättävät monipuolisuudellaan ja ovat myös tulkinnallisesti antoisia. Kirjan ajallinen rajaus on kapea ja kattaa ainoastaan kaksi vuosikymmentä.Tämän lisäksi aineistoa rajaa temaattinen keskittyminen ideologisesti värittyneisiin runoihin. Huolella rajattu näkökulma mahdollistaa aineiston syvällisen tarkastelun, ja sen avulla tutkimus kykenee täydentämään ja laventamaan kuvaa aikakauden lyriikan aatteellisuudesta.

Kirjan johdannossa aineiston tarkastelua ja tutkimuksen kohteena olevien runoilijoiden tuotantoa taustoitetaan tarkastelemalla 60-luvun runouden suhdetta suomenruotsalaiseen modernismin traditioon. Yhtenä juonteena aikakauden nuoremman runoilijasukupolven kritiikissä oli pyrkimys avata lyriikka arkisille, ajankohtaisille ja poliittisesti kantaaottaville aiheille. Johdanto tarjoaa tiiviissä muodossa informatiivisen katsauksen aikakauden suomenruotsalaiseen kulttuurikeskusteluun ja problematisoi toisinaan yksiulotteisena näyttäytyvää 60-luvun modernismikritiikkiä. Kriittisten äänenpainojen ja etäisyyden ottojen ohella esiin nostetaan myös arvostava suhtautuminen varhaisempaan suomenruotsalaiseen lyriikkaan. 
Tutkimus rakentuu kirjailijakohtaisesti ja etenee 1950-luvulla esikoisteoksensa julkaisseista Gösta Ågrenista ja Lars Huldénista vuonna 1962 debytoineeseen Claes Anderssoniin. Kullekin kirjailijalle suodaan oma lukunsa. Huomion kohdistaminen paljon luettujen ja korkealle arvostettujen runoilijoiden varhaistuotantoon tuo esiin uusia puolia runoilijoista. Näin on etenkin Ågrenin kohdalla, jonka nuoruudentuotanto on myöhemmin kokonaan unohdettu. Unohdusta ovat edesauttaneet niin varhaistuotannon aatteellisuutta vieroksunut kirjailija itse kuin tutkijat, jotka eivät ole pitäneet varhaistuotantoa yhtä korkeatasoisena kuin myöhempää tuotantoa.Aiheellisesti Möller-Sibelius kuitenkin muistuttaa, ettei tutkijan ole mitään tarvetta ottaa annettuna runoilijoiden omia mielipiteitä teostensa kirjallisesta arvosta tai merkityksestä.

Tutkimuksen metodia tekijä luonnehtii lähilukuun perustuvaksi temaattiseksi analyysiksi, jossa näkökulma on aatehistoriallinen ("en tematisk analys med textnära läsningar ur ett idéhistoriskt perspektiv", Möller-Sibelius: 24). Lukutapa on samanaikaisesti historiallisesti kontekstualisoiva ja korostetun tekstilähtöinen. Runoilijoiden poetiikan hahmottelussa lähteenä on käytetty kirjailijoiden aineistoa myös myöhemmiltä vuosikymmeniltä.Aikalaiskuvaa taas luodaan runsasta sanomalehtikritiikkiä ja päivälehtien kulttuurikeskustelua apuna käyttäen.

Lukujen otsikoissa nostetaan esiin jokin kirjailijan 60- ja 70-luvun tuotantoa erityisesti luonnehtiva poeettinen piirre: Gösta Ågrenin kohdalla paradoksaalisuus, Lars Huldénin kohdalla polyfonia ja Claes Anderssonin kohdalla dialektiikka. Kiteytykset luovat kiinnekohtia aineistoon ja auttavat lukijaa orientoitumaan analyyseihin. Ågrenin runoudessa vaikuttaa vasemmistolaisen ideologian ohella romanttis-idealistinen ajatusmaailma, ja Ågren esitetään modernina subliimin tradition jatkajana. Claes Anderssonia käsittelevässä luvussa korostuvat lyriikan ruumiillisuus sekä ruumiillisuuden yhteiskunnallinen ulottuvuus. Keskeinen käsite tässä luvussa on hegeliläinen dialektiikka. Luku tarkastelee sitä, miten Anderssonin runot toisinaan synnyttävät synteesejä ja toisinaan jättävät ristiriidat lukijan ja tulkitsijan ratkaistaviksi. Lars Huldénin runoja puolestaan analysoidaan intertekstuaalisuuden ja diskurssinanalyysin keinoin, ja keskiössä on nationalistisen ja kristillisen diskurssin purkaminen runouden keinoin.

Kokonaisuus näyttäytyy lukijalle ehyenä ja yhtenäisenä, vaikka kohdekirjailijoiden valinnassa on tekijän omien sanojen mukaan ollut hankaluutensa. Möller-Sibelius valittelee naiskirjailjoiden poisjäämistä lopullisesta aineistosta. Teoksen runoilijavalinta osoittautuu kuitenkin varsin oivalliseksi, sillä kullakin runoilijalla on erilainen suhde vasemmistolaiseen ideologiaan eikä aatteellisuus heidän tuotannossaan rajaudu aikakauden kulttuurikeskustelua hallinneeseen marxilaisuuteen ja vasemmistolaisuuteen. Gösta Ågren kuului nuoruudessaan kommunistiseen puolueeseen mutta sanoutui myöhemmin irti kommunismista monien muiden vasemmistointellektuellien tavoin. Claes Andersson edusti puoluepoliittisesti vasemmistoliittoa ja toimi myöhemmin kansanedustajana, puoluejohtajana ja ministerinä. Lars Huldén, jolla ei ollut puoluepoliittista taustaa, toimii 
kiinnostavana vertailukohtana avoimemmin aatteellisille Ågrenille ja Anderssonille. Hänen runoistaan välittyy skeptinen asenne ideologioihin, erityisesti kristinuskoon ja nationalismiin. Huldénia ei runoilijana kiinnostanut kristinuskon opillinen sisältö tai uskonto elämänkatsomuksena, vaan uskontoa lähestytään ensisijaisesti traditiona ja kielellisenä ja toiminnallisena kategoriana ("religiositet som form, yttre handling och språklig tradition”, Möller-Sibelius: I46).

Möller-Sibeliuksen diskurssianalyyttinen lukutapa on hedelmällinen ja tavattoman kiinnostava, mutta se herättää myös lisäkysymyksiä ideologian käsitteen määrittelystä ja merkityksistä. Kysymystä kielen ja diskurssin suhteesta ideologiaan olisi ollut syytä tarkentaa ja lisävalaista.

Varsinaisesti ideologian tutkimukseen ja teoretisointeihin liittyvää tutkimuskirjallisuutta hyödynnetään teoksessa vain vähän. Lisäksi ideologian käsite, johon teos tukeutuu, esitetään johdannossa vain hyvin yleistajuisesti ja pintapuolisesti. Ideologia määritellään yleisemmin yhteiskunnallisena katsantona ("samhällelig åskådning", Möller-Sibelius: 26). Lukija kaipaa tarkempaa määrittelyä, joka mahdollistaisi käsiteltyjen ilmiöiden hienosyisemmän suhteuttamista toisiinsa. Tähän laajempi teoreettinen kirjallisuus olisi varmasti tarjonnut välineitä. Määrittelyn väljyys on kuitenkin perusteltavissa sillä, että se mahdollistaa hyvin erityyppisten aatteellisten ilmiöiden käsittelyn yhdessä.

Vaikka kirjan tehtävänä on runon ja ideologian suhteen tarkastelu, tutkimuksella on paljon sanottavaa myös aineiston runojen suhteesta lyriikan traditioon. Aineistosta löytyy yhteyksiä muun muassa paimenrunouteen, tilapäisrunouteen, luontolyriikkaan ja keskeislyriikkaan. Kirjan jokaisen analyysiluvun lopuksi käsitellään metapoeettisia aiheita ja kielen, runon ja hiljaisuuden merkityksiä kunkin runoilijan tuotannossa. Teoksen otsikon kahdesta käsitteestä, Dikt och ideologi, hallitsevaan asemaan nousee lopulta runo. Ideologia toimii teoksessa yhtenä tulokulmana tarkasteltavien tekstien tematiikkaan ja poetiikkaan.

\section{Kirjoittaja}

Eeva-Liisa Bastman FT, tutkija Suomalaisen Kirjallisuuden Seura \& Helsingin yliopisto, eeva-liisa.bastman@finlit.fi 